\title{
PENERAPAN VIDEO PEMBELAJARAN DARING ANAK USIA DINI PADA MASA PANDEMI COVID-19
}

\author{
Imam Syafi'i ${ }^{1}$, Chalimatus Sa'diyah ${ }^{2}$, Elfa Wahyu Wakhidah ${ }^{3}$, Fiqi Maslakhatul Umah ${ }^{4}$ \\ ${ }^{134}$ Universitas Islam Negeri Sunan Ampel Surabaya, Indonesia \\ ${ }^{2}$ RA Muslimat NU 10 Banin-Banat Gresik, Indonesia \\ Imamsyafii.iwa@gmail.com
}

\begin{abstract}
The Covid-19 pandemic has an impact on the field of education, especially early childhood education. Online learning is of course carried out with various platforms and media to support teaching and learning activities. In early childhood, learning media is one of the supporting tools for learning so that the selection is adjusted and considered. Therefore this study wants to review the learning media used in learning in early childhood. The purpose of this study was to determine the application and content of online learning videos used as learning media at RA Muslimat NU 10 Banin Banat Gresik during the COVID-19 pandemic. The method in this research uses qualitative research, which describes the learning media used and its application in RA Muslimat Nu 10 Banin-Banat Gresik. Data collection techniques used in this study were observation, interviews, and documentation. The results of this study are online learning media in the form of videos; the stages of making online learning videos in the form of planning, procurement, storage, and evaluation in the learning media, and also explaining the contents of online learning videos. So it can be concluded that the online learning videos contain the results of the teacher's video shooting classroom teaching activities that the teacher himself makes in turns and then shares via Whatsappgroup. With this medium, children become more confident and feel as if they are studying in a normal school. While the content of the learning video is detailed and detailed regarding the material that the teacher delivers to the child. So that children and parents understand the activities or material presented by the teacher in the video.
\end{abstract}

Keywords: instructional media; online learning; instructional videos

\begin{abstract}
Abstrak
Adanya pandemi Covid-19 memberikan dampak pada bidang pendidikan terutamapendidikan anak usia dini. Pembelajaran secara daring tentunya dilakukan dengan berbagai platform dan media sebagai penunjang kegiatan belajar mengajar. Penelitian ini ingin meninjau media pembelajaran yang digunakan dalam pembelajaran pada ank usia dini dan mengetahui penerapan dan isi video pembelajaran daring yang digunakan sebagai media pembelajaran di RA Muslimat NU 10 Banin Banat Gresik selama masa pandemic COVID-19. Metode penelitian ini menggunakan jenis penelitian kualitatif yaitu mendeskripsikan media pembelajaran yang digunakan dan penerapannya di RA Muslimat Nu 10 Banin-Banat Gresik. Teknik pengumpulan data menggunakan observasi, wawancara, dan dokumentasi. Hasil dari penelitian ini adalah media pembelajaran daring berupa video; tahapan pembuatan video pembelajaran daring berupa perencanaan, pengadaan, penyimpanan, dan evaluasi dalam media pembelajaran tersebut, dan juga menjelaskan isi video pembelajaran daring. sehingga dapat disimpulkan bahwa video pembelajaran daring berisi hasil video guru syuting kegiatan mengajar di kelas yang dibuat sendiri oleh guru secara bergilir kemudian di share melalui Whatsappgroup. Dengan media ini anak menjadi lebih percaya dan seolah-olah belajar di sekolah normal. Sedangkan isi dari video pembelajarannya rinci dan detail terkait materi yang disampaikan guru kepada anak. Sehingga anak maupun orangtua memahami kegiatan atau materi yang disampaikan guru dalam video tersebut.
\end{abstract}

Kata Kunci: media pembelajaran; pembelajaran daring; video pembelajaran 


\section{PENDAHULUAN}

Coronavirus Disease (Covid-19) adalah virus yang menjadi permasalahan besar bagi seluruh dunia. Pada tanggal 2 Maret 2020 Coronavirus Disease (Covid-19) ditemukan pertama kali di Indonesia.(COVID-19, n.d.) Dengan adanya Virus ini pemerintah mengeluarkan berbagai kebijakan guna pemutusan rantai penyebaran Coronavirus Disease (Covid-19). Pembatasan aktivitas adalah salah satu kebijakan dari pemerintah harus dijalani warga Indonesia. Salah satu sektor yang mengalami pembatasan aktivitas dalam melakukan kegiatan adalah sektor pendidikan. Dampak dari adanya Coronavirus Disease (Covid-19) ini terjadi pada semua kalangan baik dari jenjang prasekolah hingga perguruan tinggi mengalami beberapa perubahan kebijakan seperti halnya yang dikatakan menteri pendidikan dan kebudayan RI dalam Surat Edaran No.3 dan Surat Edaran No.4 tahun 2020. Masa darurat penyebaran Covid-19 secara otomatis satuan pendidikan dan pelaksanaan kebijakan pendidikan harus menggunakan dua kebijakan mendikbud tersebut sebagai acuannya. Pembelajaran jarak jauh (daring) atau biasa dikenal dengan belajar di rumah adalah kebijakan yang dikeluarkan oleh Mendikbud.(SE Mendikbud, 2020)

Pandemi Covid-19 menyebabkan banyak negara yang memutuskan untuk menutup semua lembaga jejang pendidikan. Menurut data Organisasi Pendidikan, Keilmuan, dan Kebudayaan PBB (UNESCO), terdapat 290,5 juta siswa di seluruh dunia yang mengalami gangguan dalam kegiatan belajar mengajar akibat ditutupnya sekolah karena adanya pandemi Covid-19 yang terjadi secara tiba-tiba. Menurut Jonsson, siswa yang menghadiri sekolah akan meningkatkan kapasitas memorinya (Jonsson et al., 2017). Sedangkan menurut Lavy, dampak yang ditimbulkan pada pembelajaran karena adanya perbedaan waktu pengajaran di seluruh dunia. Total megajar mingguan matematika, bahasa dan sains lebih tinggi di Denmark daripada di Austria. Sehingga siswa akan kehilangan waktu belajar di sekolah yang akan merugikan siswa dan tergerusnya pengetahuan mereka (Lavy, 2010).

Dampak adanya pandemi Covid-19 terhadap pendidikan diantaranya, peserta didik mengalami keterpaksaan dalam belajar tanpa sarana dan prasarana di rumah yang memadahi, peserta didik belum pernah melakukan kegiatan belajar dengan jarak jauh, sekolah diliburkan terlalu lama sehingga membuat peserta didik jenuh di rumah, adanya biaya tambahan dalam pembelian kuota internet, guru dituntut untuk beradaptasi cepat dengan teknologi dan kepemilikan sarana dan prasarana yang memadahi (Purwanto et al., 2020, p. 9). Adapun 
dampak lainnya ialah adanya perbedaan atmosfer saat belajar di kelas dengan belajar di rumah, pemantauan perkembangan anak menjadi terbatas, guru kurang leluasa dalam kegiatan mengajar (Satrianingrum \& Prasetyo, 2020, p. 638).

Pendidikan anak usia dini adalah salah satu jenjang pendidikan yang juga mengalami dampak adanya penyebaran Covid-19. Menurut Yuliani dalam Vivi anak usia dini adalah suatu individu yang mengalami terjadinya proses tumbuh kembang yang sangat pesat bagi kehidupan berikutnya. Anak usia dini adalah pribadi yang mengalami pertumbuhan dan perkembangan dengan bantuan orang dewasa dalam memaksimalkan kinerja otak, sehingga anak mengalami perkembangan sesuai dengan tingkat perkembangannya.(Margiani, 2014, p. 11) Pentingnya anak usia dini dalam memperoleh pendidikan maka lembaga pendidikan pada jenjang PAUD banyak yang melakukan pembelajaran jarak jauh (daring) guna terlaksananya pembelajaran dengan normal untuk meningkatkan tumbuh kembang anak tetap optimal. Seperti halnya penelitian yang dilakukan oleh Khirjan, aktivitas utama yang digunakan dalam pembelajaran PAUD adalah penugasan, Home visit, dan laporan harian anak. dalam kegiatan laporan harian anak walimurid melakukannya dengan Daring (Nahdi et al., 2020, p. 177). Dengan pembelajaran daring pada masa pandemi tentunya yang berperan apenting adalah orangtua, yaitu dukungan dari orangtua maupun lingkungan keluarga sangat diperlukan anak dalam menumbuhkan motivasi belajar pada masa pandemi ini. Seperti halnya pada teori Maslow bahwa motivasi adalah usaha manusia dalam memenuhi kebutuhan untuk dapat mengembangkan semua potensi yang dimiliki (2009, p. 202).

Peran teknologi dalam pendidikan mengalami banyak permasalahan dan memiliki banyak hal yag perlu untuk dikaji. Adanya pandemi Covid-19 yang tidak terduga membuat adanya perubahan kegiatan pembelajaran yang digantikan melalui teknologi yang berkembang saat ini. Pentingnya teknologi digital dalam kehidupan, mengubah cara berkomunikasi dan juga mengubah cara otak bekerja dengan cepat dan mendalam (Mancaniello, 2020, p. 39). Guru saat ini dihadapkan dengan berbagai platform dan alat digital yang selalu berubah dalam menyampaikan konten baru mereka. Guru melakukan peralihan dari kegiatan model tatap muka ke platform online tanpa adanya pelatihan sebelumnya, dukungan yang mudah diakses dan pemodelan praktik terbaik. Menurut Fullan dalam Ruth McQuirter, banyak guru yang masih dalam Disrupsi, berurusan dengan aspek teknis penyampaian, dan tidak dapat mengajukan pertanyaan yang lebih tentang kebutuhan aspek perkembangan yaitu kognitif, sosial, dan emosional anak-anak di lingkungan online 
(McQuirter, 2020, p. 49).

Berbagai aplikasi pembelajaran daring bisa diterapkan dalam dunia pendidikan. Seperti aplikasi Google Classroom, Google Meet, Youtube, Whatsapp dan masih banyak lainnya. Namun tidak menutup kemungkinan ada yang belum terbiasa menggunakan platform ini dalam kesehariannya sehingga adanya hambatan (Zainal et al., 2020, p. 66). Seperti halnya yang dikatakan Gunawan, Platform yang yang mampu mendukung implementasi pembelajaran daring dapat berupa WhatsApp, Email, Google Classroom, Moodle, Zoom, dan yang lainnya (Gunawan et al., 2020). Sedangkan menurut Arizona, Edmodo adalah salah satu aplikasi yang dapat digunakan sebagai platform yang memiliki kelebihan untuk memudahkan guru maupun orangtua dalam memantau anak (Zainal et al., 2020).

Menurut Cristina, alat komunikasi dalam belajar jarak jauh dibagi menjadi dua yaitu Asinkron (email, blog, tutorial video dll) dan Sinkron (konferensi audio/video). Komunikasi Asinkro adalah pengiriman pesan yang dapat ditanggapi setiap saat sedangkan Komunikasi Sinkron terjadi dalam waktu nyata dan peserta harus melakukan login pada waktu yang sama (Tartavulea et al., 2020, p. 922). Sedangkan menurut Elfrianto, pembelajaran online ada dua yaitu komunikasi online sinkron, obrolan teks dan obrolan video yang dilakukan secara bersama-sama (whatsapp, messenger, Hangouts) sedangkan yang kedua adalah komunikasi online asynchronous, komunikasi yang dilakukan tertunda dan tidak dilakukan bersama-sama. Dalam penerapannya, komunikasi online ini memiliki banyak kelemahan. Diantaranya, guru tidak mengetahui sejauh mana tingkat pemahaman siswa, dibutuhkannya banyak konsentrasi karena tidak sesuainya tempat dan waktu (Elfrianto et al., 2020, p. 168). Namun menurut Cristina, pembelajaran online memiliki dampak positif pada proses pendidikan, meskipun efektivitas dari pengalaman pendidikan online dianggap lebih rendah dibandingkan dengan kegiatan tatap muka (Tartavulea et al., 2020, p. 920).

Pembelajaran daring tidak mudah dilakukan terutama untuk jenjang pendidikan anak usia dini. Banyak yang harus dipertimbangkan sebelum penentuan platform, memperhatikan baik dari sisi latar belakang orangtua, pekerjaan orangtua dan kondisi anak. Guru, walimurid, dan anak akan berperan serta dalam pembelajaran daring. Guru dan walimurid dituntut untuk bisa menjalankan aplikasi yang digunakan sebagai platform dalam kegaitan belajar mengajar. Banyaknya pilihan platform yang digunakan dalam kegiatan belajar mengajar tentunya banyak pula media yang akan digunakan dalam pembelajaran melalui platform yang dipilih. media pembelajaran sangat penting dalam proses belajar anak anak. pemilihan media tentunya 
harus menyesuikan dengan keadaan, kebutuhan dan kemampuan siswa.

Media pembelajaran adalah suatu hal yang strategis dalam proses pembelajaran karena media adalah suatu penghubung informasi yang akan diberikan guru kepada anak. Menurut Yusuhadi dalam penelitian Sita, media pembelajaran adalah semua yang digunakan untuk menyalurkan pesan serta dapat merangsang pikiran, perhatian, perasaan, dan kemauan pembelajar sehingga terjadinya proses belajar yang disengaja, bertujuan dan terkendali (Mawarti, 2018, p. 13). Sedangkan menurut Aqib, media adalah sarana alat bantu guru dalam mengajar yang membawa informasi atau pesan dari sumber belajar kepada siswa (Aqib, 2013, p. 50). Adapun menurut Abdul, media pembelajaran sebagai alat bantu kegiatan belajar mengajar untuk menyampaikan pesan agar mudah diterima dan dapat mengaktifkan dan memotivasi siswa dalam belajar (Syukur \& Fallo, 2019, p. 3). Sehingga dapat disimpulkan bahwa media adalah segala sesuatu yang menjadi perantara atau penghubung yang dapat memberikan informasi yang dapat merangsang pikiran, perasaan dan perhatian siswa sehingga terdorong dalam kegiatan belajar. Menurut Hujair dalam penelitian Ken, tujuan media pembelajaran adalah sebagai alat mempermudah proses pembelajaran, meningkatkan efisiensi proses pembelajaran, membantu konsentrasi anak dalam kegiatan belajar (Mukholladah, 2018, p. 15).

Media dapat dikelompokkan menjadi tiga bagian, yaitu media visual, media audio, dan media audio visual. Media visual adalah media yang menampilkan gambar atau tulisan yang akan nampak pada layar, sedangkan media audio adalah pesan yang berupa auditif (hanya dapat didengar), sesuai dengan namnya media audio visual yaitu penggabungan antara media visual dengan media audio, media yang mempunyai unsur gambar dan unsur suara. Salah satu media audio visual adalah video pembelajaran. Video dikatakan sebagai suatu medium yang efektif dalam membantu proses pembelajaran (Zaman \& Eliyawati, 2010). Dengan adanya pandemi Covid-19, banyaknya sekolah yang ditutup oleh karena itu Kementrian pendidikan di Argentina melakukan aksi memproduksi dan menyiarkan konten pendidikan. Hal ini dilakukan dengan tujuan agar lembaga-lembaga menyediakan sarana dan prasarana yang dibutuhkan untuk memproduksi konten pendidikan dan budaya baik berupa format radio, audio visual, dan editoral untuk seluruh sistem pendidikan (Mendonça, 2020, p. 4).

Semakin berkembangnya teknologi saat ini membuat guru berfikir ulang terkait media pembelajaran yang akan digunakan dalam masa pandemi ini. Mengingat dalam masa ini anakanak melakukan kegiatan belajar di rumah, dengan adanya teknologi yang canggih anak-anak 
dapat melakukan kegiatan belajar. Seperti halnya pada penelitian Meyda dan Aninditya, pembelajaran dari Rumah dilaksanakan di PAUD menggunakan tekonologi yang berkembang di masyarakat yaitu melalui WhatsApp group. Penerapan pembelajaran daring paling banyak dilakukan dengan menggunakan aplikasi WhatsApp (Gunawan et al., 2020; Purwanto et al., 2020). Pemberian tugas adalah metode yang diberikan guru kepada anak-anak melalui whatsapp group namun bukan hanya berupa teks saja melainkan biasanya berupa foto, dan juga rekam suara (Hutami \& Nugraheni, 2020). sedangkan pada penelitian yang dilakukan oleh La Hewi, pembelajaran daring dilakukan dengan pemberian softfile Rencana Pelaksanaan Pembelajaran Harian kepada orangtua melalui whatsappgroup kemudian anak-anak belajar bersama orangtua. Lalu memberikan hasil dokumentasi kegiatan atau hasil kerja anak melalui whatsappgroup (Hewi \& Asnawati, 2020). Sama seperti penelitian Renti, pembelajaran daring dilakukan melalui whatsappgroup dengan metode pengiriman laporan tugas (Oktaria \& Putra, 2020). Dari beberapa penelitian teradahulu memeparkan bahwa banyak jenjang pendidikan PAUD yang menggunakan platform whatsappgroup dengan berbagai media yang dipilih.

Menurut Les Giblin dalam bukunya skill with people mengatakan bahwa bagaimana manusia belajar dalam kesehariannya, $83 \%$ melalui penglihatan $11 \%$ melalui pendengaran, 3,5\% melalui penciuman, 1,5\% melalui sentuhan dan 1\% melalui rasa (Giblin, 2005, p. 1). Maka dengan adanya teori ini dapat kita simpulkan bahwa kegiatan belajar mengajar dibutuhkan media pembelajaran yang efektif melalui penglihatan dan pendengaran, karena dengan dua indra ini pembelajaran akan dinilai efektif. Oleh sebab itu media pembelajaran berupa video adalah media yang dinilai cukup efektiv dalam pembelajaran anak usia dini.

Salah satu media pembelajaran dengan memanfaatkan teknologi adalah media pembelajaran video interaktif, melalui media ini anak-anak akan ditampilkan animasi, gambar, dan audio visual yang akan sangat membantu anak dalam fokus belajar guru juga lebih percaya diri dalam menyampaikan informasi. Seperti halnya pada penelitian yang dilakukan Luh Made Indria Dewi dan Ni Luh Rimpiati, penggunaan media pembelajaran berupa video interaktif dapat menghubungkan perkembangan kognitif emosional, dan psikomotorik siswa. Video dapat memberi guru lebih banyak fleksibilitas dan mempelajari prespektif dari siswa. Video dapat dijadikan media pembelajaran yang lebih efektif (Dewi \& Rimpiati, 2015). Sedangkan menurut Reni, adanya pengaruh pengguanaan video kartun mencampur warna terhadap kemampuan kognitif pada anak (Rahayu, 2013). Sedangkan penelitian serupa juga dilakukan oleh Lely Suryani, menggunakan video sebagai media 
pembelajaan ditemukannya peningkatan perilaku cinta lingkungan setelah anak melihat video pembelajaran perilaku cinta lingkungan sebesar $45 \%$ peningkatan (Suryani \& Seto, 2020). Seperti halnya menurut Ullil, penggunaan media pembelajaran berbasis video diminati anak, hasil belajarnya juga lebih baik setelah menggunakan video pembelajaran (Fahri, 2020).

Dari pemaparan diatas terlihat jelas banyak yang telah melakukan penelitian terkait media pembelajaran berupa video pembelajaran, namun perlu untuk diteliti lebih lanjut terhadap anak usia dini. Pada penelitian-penelitian sebelumnya dilakukan pada saat kegiatan belajar mengajar normal atau tidak sedang terjadi pandemi seperti yang peneliti lakukan saat ini. Maka peneliti ingin mengkaji lebih lanjut terkait media pembelajaran daring di RA Muslimat NU 10 Banin Banat. Bagaimana bentuk video pembelajaran yang diberikan dan bagaimana penerapannya dalam anak usia dini. Pemilihan media yang bervariasi dengan menyesuaikan platform yang dipilih tentunya menjadi salah satu pertimbangan sekolah maupun guru dalam menentukan media yang akan digunakan. Keadaan lapangan di RA Muslimat NU 10 Banin Banat, menggunakan video sebagai media pembelajaran daring dengan platform whatsapp group dengan media video pembelajaran.

Penerapan kebijakan pembelajaran daring pada masa pandemi telah berjalan dan belum ditemukan hasil penelitian yang mengungkap penerapan video pembelajaran daring baik segi isi, alasan pemilihan video sebagai media, perencanan awal maupun penerapannya. Hasil penelitian ini dapat dimanfaatkan untuk menyempurnakan kebijakan khususnya terkait pembelajaran daring di jenjang PAUD, oleh karena itu penelitian ini perlu untuk dilakukan. Penelitian ini juga diharapkan bermanfaat bagi guru maupun orangtua dalam memberi informasi pengetahuan atau mengajar anak keika di rumah, melalui video pembelajaran akan berdampak seperti apa terhadap anak. bagi peneliti selanjutnya juga diharapkan dapat melakukan penelitian lanjutan dari penelitian ini. Tujuan penelitian ini yaitu untuk mengetahui bagaimana penerapan video pembelajaran daring baik dari segi isi video maupun pengaplikasiannya. Dari uraian diatas, maka perlunya penelitian lebih lanjut mengenai penerapan video pembelajaran daring Anak Usia Dini di RA Muslimat NU 10 Banin Banat Gresik.

\section{METODE PENELITIAN}

Metode penelitian ini menggunakan jenis penelitian kualitatif deskriptif. Yaitu penelitian yang mendeskripsikan peristiwa nyata, fleksibel, dan terbuka. Desain penelitian 
kualitatif bersifat fleksibel dan terbuka sedangkan datanya bersifat deskriptif yaitu berupa gejala yang dikelompokkan atau berupa lainnya seperti dokumen, foto, catatan lapangan pada saat dilakukannya penelitian, hal ini dikatakan oleh Rukin dalam bukunya.(n.d., p. 7) Menurut Halimatus Sa'diyah dalam skripsinya, metode kualitatif adalah penelitian yang menghasilkan data deskriptif berupa kata kata tertulis atau lisan dari orang-orang dan dari perilaku yang sedang diamati (Sa'diyah, 2019, p. 44).

Lokasi dalam penelitian ini dilakukan di kelompok B1 RA Muslimat NU 10 Banin Banat Gresik. Subjek dalam penelitian ini adalah kepala sekolah, 7 orang guru kelompok B, 1 orang guru kelas B1 dan 14 siswa-siswi kelompok B1 RA Muslimat NU 10 Banin Banat Gresik. Dalam pengumpulan data penelitian ini menggunakan tiga sumber data yakni observasi, wawancara, dan dokumentasi. Teknik pengumpulan data dengan menggunakan observasi atau pengamatan terhadap pembelajaran daring di masa pandemi. Observasi dilakukan melalui Non-participation observer, observasi yang dilakukan dengan turun langsung, adanya pandemi Covid-19 pembelajarannya tidak dilakukan di sekolah namun melalui daring atau melalui Whatsapp group maka peneliti akan melakukan observasi non partisipan dengan tidak terlibat langsung pada kegiatan sumber data (Yusuf, 2016, p. 384).

Wawancara adalah Suatu proses interaksi secara langsung melalui tatap muka (face to face) antara pewawancara (interviewer) dan sumber informasi atau orang yang diwawancarai (interviewee) tentang suatu objek yang diteliti dan telah dirancang sebelumnya.(Yusuf, 2016, p. 372) Peneliti menggunakan teknik wawancara terencana-terstruktur. Teknik ini digunakan untuk memperoleh informasi mengenai penerapan video pembelajaran anak usia dini di RA Muslimat NU 10 Banin Banat Gresik. Dalam penelitian ini sasaran wawancara adalah kepala sekolah, guru kelas dan siswa-siwi kelompok B1. Sedangkan guru kelompok B yang lain akan menjadi pelengkap dalam pemerolehan informasi. Dokumentasi yang peneliti peroleh adalah data-data sekolah, perangkat pembelajaran, foto maupun video kegiatan pembelajaran daring, dan juga lembar kerja anak sebagai bahan mengukur pemahaman anak terhadap video pembelajaran daring yang diberikan guru dan juga bisa digunakan sebagai bahan evaluasi media pembelajaran yang diguanakan. Berikut dokumentasi hasil pembelajaran daring yang dikirimkan oleh orangtua anak: 

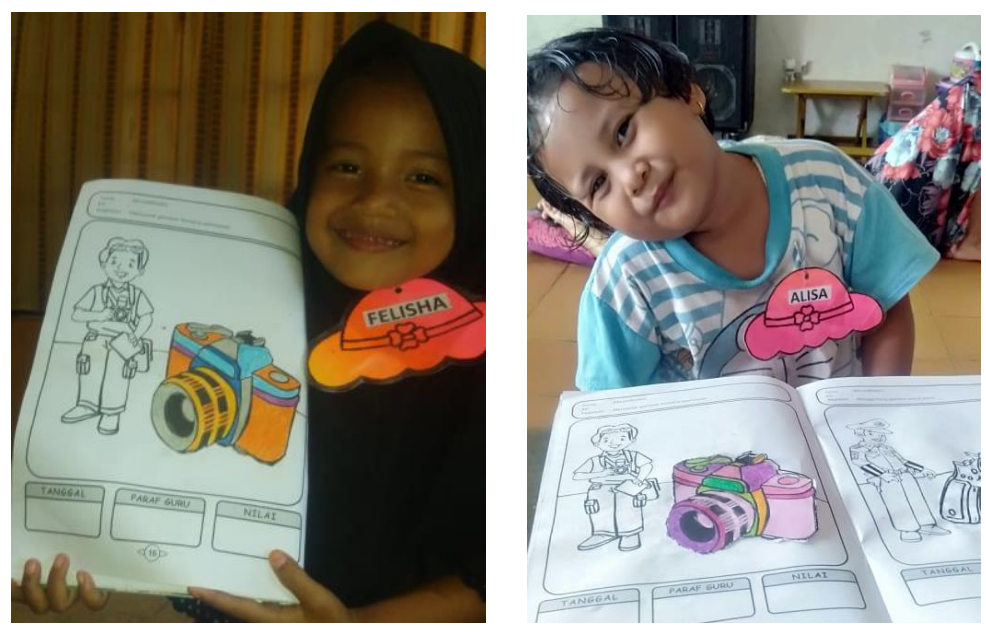

Gambar 1. Dokumentasi Hasil Pembelajaran Daring

Instumen pengumpulan data yang digunakan adalah human instrumen atau peneliti sendiri yang berfungsi menetapkan fokus penelitian, memilih informan sumber data, pengumpulan data dan analisis data serta melakukan kesimpulan. Instumen lainnya adalah pedoman wawancara dan juga lembar observasi. Setelah data terkumpul, kemudian dilakukannya analisis yang mengacu pada model analisis Miles dan Huberman, analisis data dapat melalui tiga proses atau tiga alur kegiatan yang terjadi secara bersamaan yaitu reduksi data (Data Reduction), penyajian data (Data Dispaly), dan penarikan kesimpulan (verification)(Setiawan, 2018, p. 234).

Uji keabsahan data dalam penelitian ini didasarkan dengan menggunakan triangulasi sumber, triangulasi teknik, dan triangulasi waktu. Teknik triangulasi sumber adalah Pengecekan ulang dengan wawancara kepada sumber lain menggunakan pertanyaan yang sama. Dengan tujuan untuk menggali informasi satu dengan informasi lainnya. Triangulasi teknik yaitu membandingkan hasil wawancara pertama dengan hasil wawancara selanjutnya untuk menguji kredibilitas suatu data. sedangkan triangulasi waktu yaitu pengujian data berulang kali untuk menemukan data yang relevan.

\section{HASIL PENELITIAN DAN PEMBAHASAN}

Berdasarkan hasil observasi, wawancara, dan dokumentasi yang telah dilakukan peneliti di RA Muslimat NU 10 Banin Banat Gresik, sebelum adanya pandemi Covid-19 model pembelajaran dilakukan secara normal yaitu dengan tatap muka. Namun hal itu berubah pada akhir bulan Maret dengan adanya wabah Virus Covid-19 yang terjadi diseluruh 
belahan dunia terutama Indonesia. Pada awal-awal dilakukannya kegiatan pembelajaran jarak jauh, RA Muslimat NU 10 Banin-Banat melakukan transformasi atau peralihan dari yang awalnya kegiatan belajar mengajar dilakukan di sekolah secara tatap muka, beralih pada kegiatan belajar dari rumah yang dilakukan melalui smartphone dengan platform whatsapp group. Pada saat itu kegiatan belajar mengajar dilakukan di whatsapp group dengan media berupa whatsapp teks. Guru mengirim kegiatan yang dilakukan anak-anak pada hari itu hanya dengan mengirim pesan teks di whatsapp group. Seiring bertambahnya waktu, guru RA Muslimat NU 10 Banin-Banat melakukan pengembangan dari yang awal mulanya pembelajaran melalui whatsapp teks beralih ke pembelajaran melalui video.

Pembelajaran daring melalui whatsapp teks dilakukan karena guru pada saat itu mengalami peralihan yang cepat dan mendadak sehingga, melalui media ini dinilai sebagai tindakan sementara agar tetap terlaksananya kegiatan belajar mengajar. Dengan dilakukannya evaluasi dan analisa kondisi setempat, guru RA Muslimat NU 10 Banin Banat akhirnya memutuskan menggunakan pembelajaran daring dengan media berupa video. Adapun penerapan video pembelajaran daring pada anak usia dini di RA Muslimat NU 10 Banin Banat Gresik sebagai berikut.

Media pembelajaran disiapkan sebelum dilakukannya kegiatan belajar mengajar. Sebelum diterapkan, maka ada beberapa hal yang harus dilakukan dalam membuat media pembelajaran, salah satunya melakukan perencanaan sebelum membuat media pembelajaran. di RA Muslimat Nu 10 Banin-Banat, sebelum membuat media pembelajaran melakukan beberapa hal berikut ini,

\section{Perencanaan Media Pembelajaran}

Merencanakan sebelum melakukan kegiatan adalah hal yang paling utama dilakukan agar kegiatan berhasil dan sesuai dengan yang di inginkan. Pada masa pandemi ini, tentunya melakukan perencanaan kegiatan belajar mengajar harus benar-benar diperhatikan. Yang paling utama adalah pemilihan strategi pembelajaran yang tepat, baik tujuan pembelajaran, bahan atau materi pembelajaran, karakterisitik hingga sarana dan prasarana yang menunjang kegiatan belajar mengajar (Nadia, 2020). Dalam perencanaan media pembelajaran langkah pertama adalah mengidentifikasi kebutuhan media di lingkungan pendidikan anak usia dini. Baik dilakukan melalui observasi, wawancara, maupun diskusi. Setelah ditemukannya data tentang jenis media kemudian media 
diidentifikasi kembali disesuaikan dengan tema, kemampuan dan tujuan yang akan dicapai (Zaman \& Eliyawati, 2010).

Dalam perencanaan media pembelajaran, pendidik melakukan identifikasi terkait kebutuhan dan karakteristik siswa. Sebuah perencanaan media didasarkan pada kebutuhan need, salah satu indikator adanya kebutuhan karena di dalamnya terdapat kesenjangan (2019, p. 38). Hasil wawancara dengan kepala sekolah mengatakan bahwa dengan adanya kebijakan belajar dari rumah atau biasa dikenal dengan istilah pembelajaran daring di RA Musimat NU 10 Banin Banat Gresik melakukan identifikasi dari segi latar belakang orangtua, salah satunya adalah pekerjaan orangtua. Kemudian dilanjutkan dengan mengidentifikasi peserta didiknya, baik terkait kemampuan, keterampilan maupun sikap siswa. Tentunya dengan melihat situasi dan kondisi yang ada saat pandemi Covid-19.

Latar belakang orang tua (walimurid) yang sangat variatif tentunya menyebabkan kegiatan pembelajaran daring ada yang mengalami hambatan. Di RA Muslimat $\mathrm{Nu} 10$ Banin Banat sebagian orangtua banyak yang bekerja sebagai buruh pabrik, mengingat lingkungan atau daerah setempat daerah industri. Sehingga anak-anak belajar bukan hanya bersama dengan ibu atau ayah mereka, melainkan dengan keluarga yang lain baik itu saudara atau kakek nenek. Seperti halnya yang dikatan Lulus dan Nursalim, terdapat orang tua yang bekerja, tidak memiliki handphone/ kuota internet, kurang fahamnya orang tua dengan teknologi adalah salah satu penghambat pembelajaran secara daring. seperti pada penelitian yang dilakukan Lulus banyak yang mengalami kendala pada hal ini (Mufarikhah Umar \& Nursalim, 2020, p. 606). Hal ini merupakan salah satu pertimbangan sekolah dalam penentuan media pembelajaran daring.

Penyesuaian kemampuan guru maupun walimurid tentu menjadi penentu jenis kegiatan dan media pembelajaran yang dipilih guru. Hal ini sesuai dengan pendapat Mirzon bahwa banyaknya opsi platform aplikasi belajar maupun pemilihan media yang digunakan dalam belajar daring menyulitkan guru untuk menuntut walimurid memahami, misalnya dengan media video call, zoom meeting, google meeting dan yang sejenisnya. Namun hal itu memerlukan kuota internet yang lebih besar dan memberatkan walimurid dari segi ekonomi, latar belakang orangtua pun bervariatif (Daheri et al., 2020, p. 778).

Setelah dilakukannya identifikasi, penggunaan platform yang digunakan di RA Muslimat NU 10 Banin Banat adalah penggunaan aplikasi whatsapp melalui whatsapp 
group sebagai salah satu perantara kegiatan belajar mengajar di sekolah ini. Mengingat banyaknya walimurid yang sudah mengenal aplikasi ini dan faham dalam pengoprasiannya dan fleksibel. Seperti penelitian yang dilakukan Mirzon dkk, menyatakan bahwa whatsapp adalah aplikasi yang familiar digunakan orang tua.(Daheri et al., 2020, p. 776).

Kesesuaian dengan gaya belajar anak adalah salah satu hal yang harus diperhatikan dalam pemilihan media. Gaya belajar anak-anak bervariasi, ada yang memiliki tipe gaya belajar visual seperti melihat televisi atau video, auditif yang lebih menyukai cara belajar dengan cara mendengar, maupun kinestetik yaitu gaya belajar yang lebih cenderung suka melakukan dibandingkan membaca dan mendengarkan(2019, p. 30). Seperti halnya pada teori yang dikatan Les Giblin dalam bukunya skill with people, bahwa manusia belajar paling banyak dengan cara melihat dan mendengarkan. Maka, pengambilan keputusan penggunan media video pembelajaran sebagai media dalam pembelajaran daring di RA Muslimat NU 10 dinilai tepat.

Beragam keputusan sekolah yang menerapkan pembelajaran daring melaui whatsapp baik itu dengan whatsapp chat, videocall, melalui pesan suara atau melalui video. RA Muslimat NU 10 Banin Banat memilih Video sebagai media belajar anak karena mengingat banyaknya orangtua yang bekerja sebagai buruh pabrik dengan jam kerja yang berubah-ubah. Jika dilakukannya video call atau Zoom orangtua akan mengaami kesulitan karena orangtua tidak selalu mendampingi anak saat jam sekolah, sehingga kepala sekolah dan guru menilai video pembelajaran cocok dilakukan di RA Muslimat NU 10 Banin Banat yang pembelajarannya tidak membatasi waktu atau jam belajar.

Video pembelajaran daring yang dilakukan di RA Muslimat Nu 10 Banin Banat berisi video lengkap guru seperti mengajar di kelas sebelum adanya pandemi. Guru membuka video dengan kegiatan pembuka yaitu dengan sapaan, motivasi, bernyanyi sambil berdoa maupun kegiatan agama dan moral. Kemudian dilanjut dengan kegiatan inti yang dimulai kegiatan cakap-cakap dan ditutup dengan kegiatan bernyanyi atau kegiatan praktik yang sangat disukai anak. Menurut guru kelas B1 alasan membuat video pembelajaran dengan lengkap karena agar anak-anak merasa seperti sekolah seperti sebelum adanya covid-19. Anak-anak juga dibiasakan agar nanti setelah adanya pandemi anak-anak tidak menjadi malas atau bosan saat di sekolah. 
Isi dari video pembelajaran tersebut sesuai dengan tema pada hari itu. Kegiatankegiatan yang akan dilakukan anak setelah melihat video pembelajaran dari guru sangat beragam. Misalnya kegiatan menganyam atap rumah dari daun, mencocok dengan alat yang ada di rumah seperti memakai alas spons pencuci piring dll. Hal ini akan memudahkan anak dan orangtua dalam mengikuti kegiatan belajar jarak jauh. Kegiatan agama dan moral juga selalu ditanamkan melalui video pembelajaran, sehingga anakanak berkembang sesuai dengan aspek perkembanggannya yaitu aspek kognitif, afektif dan psikomotorik. Seperti yang dikatan Hamdan, salah satu prinsip yang harus diperhatikan dalam membuat video pembelajaran adalah konten video, yaitu kesesuaian isi dengan tema (Batubara \& Ariani, 2016).

RA Muslimat NU 10 Banin Banat Gresik memutuskan media pembelajaran daring adalah video pembelajaran, video pembelajaran dinilai lebih efektif dan efisien dengan latar belakang orangtua yang pekerja. Menurut Asilestari dalam Muhdi dan Nurkolis pemilihan media yang tepat oleh guru maka proses interaksi akan terjadi secara maksimal, media audio visual merupakan media yang dapat dijadikan sebagai media interaksi yang lebih maksimal dari pada media yang lain. (2020, p. 221) Media audio visual dapat mengoptimalkan motorik anak menjadi lebih peka dan terasah, contohnya seperti komputer interaktif atau CD interaktif. Pendapat tersebut sama halnya di RA Muslimat NU 10 Banin Banat, pemberian vidio pembelajaran menjadikan anak-anak lebih tertarik dalam belajar tidak monoton, memotivasi anak dalam belajar dan tentunya anak-anak bisa melihat wajah ibu guru saat belajar. Perencanaan media pembelajaran tentunya juga menyesuiakan tema kegiatan yang akan dicapai dalam bentuk Rencana Pelaksanaan Pembelajaran Harian dengan melihat tujuan yang akan dicapai.

2. Pengadaan Media Pembelajaran

Langkah setelah dilakukannya sebuah perencanaan adalah pengadaan sumber belajar. pengadaan sumber belajar dapat diperoleh melalui beberapa cara diantaranya pembelian, menerima sumbangan atau hadiah,bekerjasama, membuat sendiri (Zaman \& Eliyawati, 2010). Dari hasil wawanacara dengan guru kelas B1, pengadaan media pembelajaran di RA Muslimat Nu 10 Banin Banat membuat sendiri. Mengingat media pembelajaran yang digunakan adalah video maka pembuatannya dilakukan sesama guru saling membantu. Pengambilan video dilakukan di lingkungan sekolah baik di dalam kelas atau di halaman sekolah. Video pembelajaran yang dibuat guru tanpa harus ada proses edit dengan 
aplikasi karena dari guru kelompok B mengalami kesulitan dari segi penggunaan aplikasi edit video. Alat atau bahan belajar pendukung, anak akan diberi dan disiapkan dari sekolah sehingga orangtua tidak kesulian mencari alat maupun bahan belajar anak.

Dari hasil observasi yang peneliti lakukan, guru membuat video pembelajaran dimulai dengan tahap-tahap di antaranya; Persiapan yakni menyiapkan RPPH dan bahan ajar lain sebagai pendukung seperti gambar, maupun lembar kerja anak; guru menyiapkan skenario atau rancangan sederhana jalannya syuting yang akan dilakukan guru; melakukan syuting bekerjasama dengan sesama guru kelas. Pada kegiatan awal guru akan menyapa anak dan memberi motivasi. Kemudian dilanjut dengan bercakap-cakap kegiatan nilai agama dan moral setelah itu dilanjut kegiatan tema. Setelah penjelasan tema anak-anak diajak guru belajar dengan lembar kerja atau praktik langsung, tentunya dengan demonstrasi dari guru; guru juga melakukan kegiatan recalling dan penutup, tidak lupa dengan pemberian motivasi; gambar atau media pendukung lain ditempelkan di papan tulis kemudian diambil rekam video dengan suara guru yang menjelaskan, dalam proses pengambilan video gruru akan menjeda video jika mereka mengalami kesalahan atau membutuhkan istirahat dalam pembuatan video; setelah perekaman video selesai guru akan melihat hasilnya kemudian akan mengirimkannya langsung ke whatsapp group guru kelompok B, kemudian ada guru yang bertugas menulis kegiatan yang akan dilakukan anak sesuai dengan isi dalam video tersebut.

3. Penyimpanan dan pemeliharaan media pembelajaran

Penyimpanan dan pemeliharaan media pembelajaran sangat penting untuk dilakukan. Mengingat media pembelajaran tidak hanya digunakan satu kali dalam kegiatan belajar. hasil wawancara yang telah peneliti lakukan dengan guru kelas kelompok B yang bertugas menyimpan video pembelajaran mengatakan bahwa video pembelajaran yang telah dibuat oleh masing-masing guru kelas akan dipindahkan atau disimpan ke laptop, agar jika suatu saat guru membutuhkan video pembelajaran ini tidak perlu susah payah membuat lagi dan pemindahan dari telepon gengam ke laptop gunanya juga untuk menghindari sistem penyimpanan ponsel yang penuh yang nantinya akan menghambat pembuatan video pembelajaran.

4. Penggunaan dan Evaluasi Media Pembelajaran

Penggunaan media secara optimal dalam pembelajaran tentunya guru harus tahu akan penggunaannya dan mengasah keterampilan guru dalam menggunakan media tersebut. 
Dengan memanfaatkan media pembelajaran yang sudah ada guru seharusnya menggunakannya secara kreati sehingga kegiatan belajar mengajar anak akan berjalan dengan efektif (Zaman \& Eliyawati, 2010). Sedangkan, penggunaan media tidak dilihat atau dinilai dari segi kecanggihan suatu media itu, melainkan yang paling penting adalah fungsi dan perannya dalam membantu peningkatan atau pemahaman dalam proses pembelajaran(Hijriani, 2019, p. 11). Pengguanaan video pembelajaran di RA Muslimat NU 10 Banin Banat digunakan secara optimal. Guru juga sangat kreatif dalam menarik perhatian anak melalui video pembelajaran yang ia buat. Video pembelajaran daring di RA Muslimat $\mathrm{Nu} 10$ Banin Banat akan digunakan atau dibagikan kepada kelompok B1,B2,B3,B4,B5,B6 dan B7. Dalam pembuatannya guru akan bergantian sehingga setiap hari anak-anak akan belajar dengan guru sesuai dengan jadwal sentra yang berbeda setiap harinya.

Evaluasi media pembelajaran perlu untuk dilakukan untuk memperbaiki atau melihat layak tidaknya media pembelajaran yang diberikan kepada anak usia dini. Dalam penilaiannya harus dilihat tujuan yang telah dibuat dengan hasil saat ini yang nampak setelah media itu diterapkan. Sehingga guru akan mudah dalam kegiatan evaluasi. Dari hasil observasi, guru RA Muslimat Nu 10 Banin Banat akan melakukan Evaluasi setiap pergantian sub tema. Guru akan melakukan evaluasi terkait alat atau bahan pendukung video pembelajaran yang cocok untuk anak-anak agar tetap menarik perhatian anak dan juga agar anak tidak mudah bosan. Dan juga mengevaluasi kesesuaian materi atau menarik tidaknya materi yang disampaikan.

5. Pengembangan Media Pembelajaran

Pengembangan media pembelajaran sangat penting dilakukan oleh guru salah satunya media visual seperti : gambar, audio, video, poster dan lain-lain. Prinsip-prinsip umum untuk merancang media adalah pembuatan media harus dapat digunakan untuk perkembangan berbagai aspek pekembangan, seperti balok untuk perkembangan motorik dan kognitif anak dimana anak mampu menyusun balok sesuai dengan ukuran atau warna balok tersebut serta sesuai dengan tingkatperkembangan anak, bahan yang digunakan tidak membahayakan bagi anak dan mudah didapatkan bisa menggunakan bahan bekas dengan mendaur ulang serta mengajarkan kepada anak untuk kreatif serta menjaga lingkungan. Menurut Guslinda dan Rita pengembangan media pembelajaran dapat dilakukan berbasis budaya. Seperti makanan, permainan, dan benda transportasi 
(Guslinda, 2018, pp. 52-64). Media untuk anak usia dini bisa melalui budaya setempat seperti jenis makanan tradisional, permainan tradisional dll. Anak-anak akan belajar dan mengenal sesuatu dengan media ini.

Pendidik Di RA Muslimat NU 10 Banin-Banat melakukan pengembangan media pembelajaran baik itu media pembelajaran yang berupa benda-benda disekitar rumah, maupun media video pembelajaran. Pengembangan media benda di sekitar rumah anak, nampak pada kegiatan membatik dengan sayur ibu yang ada di rumah. Kemudian dari segi media pembelajaran yang berupa video, pendidik mulai menambahkan variasi dalam video tersebut. Dari yang awalnya videonya polos menjadi lebih bervariasi dan tentunya lebih menarik. Kata-kata yang digunakan guru lebih menarik dan tidak membosankan. Namun, pengembangan media pembelajaran dilakukan secara perlahan dan menyesuaikan kondisi yang ada. Di RA Muslimat NU 10 Banin-Banat diharapkan media pembelajarannya berkembang menjadi yang lebih baik.

\section{Penerapan Video Pembelajaran Daring Anak Usia Dini}

Pembelajaran daring dengan menggunakan media video adalah pembelajaran dengan alat bantu berupa video yang didalamnya terdapat berbagai informasi dan kegiatan bermain. Proses pembelajaran anak usia dini berpusat pada anak, yaitu dengan mengguanakan pendekatan saintiifk, yaitu 5M mengenal, menanya, mengumpulkan, mencoba, dan mengkomunikasikan. Dengan mengguanakan pendekatan saintifik anak akan berperan aktif dalam proses belajar. RA Muslimat NU 10 Banin Banat melakukan kegiatan pembelajaran dengan pendekatan saintifik dengan alat bantu atau media video pembelajaran.

Hasil temuan data penelitian yang telah dilakukan pada kelompok B1 RA Muslimat NU 10 Banin Banat Gresik dengan jumlah siswa 14 anak. Dalam penerapan video pembelajaran, guru mengemas pembelajaran daring dengan pendekatan saintififk baik dengan metode demonstrasi, tanya jawab maupun unjuk kerja. Pendekatan saintifik yang dilakukan guru tentunya dimuali dengan kegiatan mengenal, anak-anak akan diajak mengenal tema hari ini dengan pengetahuan yang sebelumnya diketahui anak; kemudia anak-anak akan menanya diamana guru akan memberikan jeda pada video untuk memberikan kesempatan anak untuk berfikir sejenak; setelah itu pada kegiatan cakapcakap kegiatan tema, anak akan mengumpulkan banyak informasi karena banyak gambar yang diberikan guru dalam video yang dibuat. Dalam hal ini guru akan sedikit 
memberikan demonstrasi untuk memperkuat dugaan anak-anak; setelah mengumpulkan informasi, anak-anak akan mencoba kegiatan yang telah dibahas sebelumnya; dan diakhiri dengan kegiatan mengkomunikasikan, dimana anak-anak akan setor baik itu kegiatan unjuk kerja atau tanya jawab melalui rekam suara atau video yang akan dikirim orangtua kepada guru melalui whatsappgroup.

Kegiatan mengkomunikasikan dan tanya jawab yang dilakukan tidak secara langsung, anak-anak akan menunjukkan kemampuannya dalam menyampaikan informasi atau gagasan terhadap kegiatan atau temuan yang telah ia temukan. Hal ini seperti pada teori Jean Piaget tentang metode pembelajaran yang dapat mengembangkan pengetahuan, dimana dalam penerapannya pembelajaran anak dapat menggunakan metode seperti metode bercerita, demonstrasi, tanya jawab, proyek dan bermain peran(Mukholladah, 2018, p. 98).

Penerapan video pembelajaran daring di RA Muslimat NU 10 Banin Banat dilakukan dengan tahap awal yaitu perencanaan hingga evaluasi media pembelajarannya. Dalam mengimplementasikan videonya guru membagikan video pada jam sekolah atau jam anak belajar dari rumah. Hasil observasi yang telah peneliti lakukan, pembelajaran daring kelompok B1 dimulai pada pukul 07.30 WIB melalui platform whatsappgroup. Guru akan membagikan gambar jadwal belajar sentra pada hari itu, video tahfidz surat An Naba', materi kegiatan yang akan dilakukan anak di rumah, kemudian video pembelajaran. setelah video pembelajaran dibagikan, anak-anak akan belajar dari rumah bersama orangta atau kerabat saudaranya. Selang beberapa menit anak-anak akan mengirimkan ke whatsappgroup video, foto, maupun rekam suara kegiatan belajar, baik penyampaian gagasan anak maupun unjuk kerja anak sesuai dengan kemauan anak, mau divideo, rekam suara atau foto.

Guru tidak memaksakan kehendak anak dalam belajar. guru dan orangtua sudah bekerjasama jika anak-anak sedang tidak mau mengerjakan maka harus ditunggu hingga anak-anak mau mengerjakan atau dengan memberinya motivasi seperti yang dilakukan guru kelompok B1 motivasi melalui pesan suara. Dari segi pengumpulan video, foto atau rekam suara kegiatan belajar anak tidak ada batasan waktu yang singkat. Orang tua diberikan kelonggaran. Jika anak tidak ada kabar di whatsappgroup selama sehari, guru akan mencari tahu baik menghubungi orangtua atau walimurid yang lain menanyakan kabar atau adanya kendala dalam kegiatan belajar. 
Dengan menggunakan video pembelajaran sebagai media pembelajaran daring, anak akan lebih mudah memahami pembelajaran, karena dalam penyampaiannya yang dikemas guru nampak hadir meskipun melalui video, sehingga anak-anak akan tertarik dengan adanya guru. Kecenderungan anak-anak saat belajar di rumah tentunya anak banyak yang malas jika belajar bersama orangtua. Anak-anak lebih percaya dengan guru dibandingkan dengan orangtuanya. Isi video pembelajarannya pun rinci dan jelas sehingga anak maupun walimurid memahami materi yang disampaikan guru dengan baik. Banyak sekolah yang telah menggunakan teknologi canggih yang lebih efektif, namun melihat kondisi setempat yang tidak memungkinkan maka banyak sekolah disekitar yang pembelajaran daring menggunakan media rekam suara, gambar, atau hanya dengan pesan di whatsappgroup. Hal ini akan lebih membosankan untuk anak. sehingga penerapan media pebelajaran dengan menggunakan media berupa video memiliki banyak manfaat bagi anak. pengajaran akan lebih menarik dengan memberikan materi yang mendalam dan kepercayaan anak akan apa yang disampaikan guru. Penerapan media audio visual yang berupa gabungan antara suara dengan gambar akan menjadi penyampaian atau perantara pesan dengan jelas tanpa banyak tulisan atau lisan.

\section{SIMPULAN DAN SARAN}

Dari hasil penelitian dapat disimpulkan bahwa media pembelajaran yang digunakan di RA Muslimat NU 10 Banin Banat pada masa pandemi berupa video pembelajaran yang dibuat oleh guru yang bertugas mengajar pada hari itu atau guru melakukan syuting mengajar yang nantinya akan langsung dikirim melalui aplikasi Whatsaap group wali murid. Sebelum memutuskan penggunaan video pembelajaran sebagai media pembelajaran daring, pendidik di RA Muslimat NU 10 Banin Banat melakukan kegiatan perencanaan terlebih dahulu kemudian baru dilakukan penerapannya. Video pembelajaran dinilai cukup menyita perhatian anak dalam belajar dari rumah, sehingga anak-anak tertarik atau munculnya motivasi belajar karena video pembelajaran yang menampilkan wajah ibu guru di RA Muslimat NU 10 Banin Banat. Dalam penelitian ini ditemukan isi video pembelajaran yang full dan rinci sehingga anak dan orangtua memahami kegiatan belajar yang dilakukan pada hari itu. Sehingga tidak menimbulkan kebingungan atau komunikasi yang kurang jelas antara guru dengan anak, maupun guru dengan orangtua dalam mendampingi anak belajar. 
Sesuai dengan hasil penelitian ini, dapat diberikan saran sebagai berikut, dalam pembuatan video pembelajaran ada baiknya dibuat lebih menarik seperti penambahan efek, animasi, ataupun musik yang dapat menarik ,imat anak dalam belajar. Bagi penelitian selanjutnya, penelitian ini menunjukkan hasil yang cukup efektif dalam pengembangan media berupa video pembelajaran, sehingga disarankan untuk mengembangkan lagi penelitian ini dengan memodifikasi.

\section{DAFTAR PUSTAKA}

Alwisol. (2009). Psikologi Kepribadian. UMM Press.

Aqib, Z. (2013). Model-model, media, dan strategi pembelajaran kontekstual (inovati). YramaWidya.

Batubara, H. H., \& Ariani, D. N. (2016). Pemanfaatan Video sebagai Media Pembelajaran Matematika SD/MI. Muallimuna: Jurnal Madrasah Ibtidaiyah, 2(1), 47-66. https://doi.org/10.31602/muallimuna.v2i1.741

COVID-19, G. T. P. P. (n.d.). Peta Sebaran | Gugus Tugas Percepatan Penanganan COVID-19. Covid19.Go.Id. Retrieved July 5, 2020, from https://covid19.go.id/peta-sebaran

Daheri, M., Juliana, Deriwanto, \& Dibul Amda, A. (2020). Efektifitas WhatsApp sebagai Media Belajar Daring. Jurnal Basicedu, 4, 77-783.

Dewi, L. M. I., \& Rimpiati, N. L. (2015). Efektivitas Penggunaan Media Pembelajaran Video Interaktif Dengan Seting Diskusi Kelompok Kecil Untuk Meningkatkan Keterampilan Berpikir Kritis Pada Anak Usia Dini. JEPUN: Jurnal Pendidikan Universitas Dhyana Pura, 1(1). https://jurnal.undhirabali.ac.id/index.php/Jepun/article/view/78

Elfrianto, E., Dahnial, I., \& Tanjung, B. N. (2020). The Competency Analysis Of Principal Against Teachers In Conducting Distance Learning In Covid-19 Pandemic. Jurnal Tarbiyah, 27(1). https://doi.org/10.30829/tar.v27i1.704

Fahri, M. U. (2020). Pemanfaatan Video Sebagai Media Pembelajaran. OSF Preprints. https://doi.org/10.31219/osf.io/z97qy

Giblin, L. (2005). Skill with people. PT Gramedia Pustaka Utama.

Gunawan, G., Suranti, N. M. Y., \& Fathoroni, F. (2020). Variations of Models and Learning Platforms for Prospective Teachers During the COVID-19 Pandemic Period. Indonesian Journal of Teacher Education, 1(2), 61-70.

Guslinda. (2018). Media Pembelajaran Anak Usia Dini. INA-Rxiv. https://doi.org/10.31227/osf.io/4c2hx

Hewi, L., \& Asnawati, L. (2020). Strategi Pendidik Anak Usia Dini Era Covid-19 dalam Menumbuhkan Kemampuan Berfikir Logis. Jurnal Obsesi: Jurnal Pendidikan Anak Usia Dini, 5(1), 158-167. https://doi.org/10.31004/obsesi.v5i1.530

Hijriani, D. (2019). Media Pembelajaran Sains Terpadu (Rancang Bangun Media Pembelajaran Sains Berbantuan Komputer). INA-Rxiv. https://doi.org/10.31227/osf.io/9wun2

Hutami, M. S., \& Nugraheni, A. S. (2020). Metode Pembelajaran Melalui Whatsapp Group Sebagai Antisipasi Penyebaran Covid-19 pada AUD di TK ABA Kleco Kotagede. PAUDIA : Jurnal Penelitian Dalam Bidang Pendidikan Anak Usia Dini, 9(1), 126-130.

Jonsson, B., Waling, M., Olafsdottir, A. S., Lagström, H., Wergedahl, H., Olsson, C., Fossgard, E., Holthe, A., Talvia, S., Gunnarsdottir, I., \& Hörnell, A. (2017). The Effect of Schooling on Basic Cognition in Selected Nordic Countries. Europe's Journal of Psychology, 13(4), 645666. https://doi.org/10.5964/ejop.v13i4.1339 
Lavy, V. (2010). Do Differences in Schools' Instruction Time Explain International Achievement Gaps? Evidence from Developed and Developing Countries (No. w16227). National Bureau of Economic Research. https://doi.org/10.3386/w16227

Mancaniello, M. R. (2020). Adolescenti al tempo del Covid-19: Una riflessione sul significato di vivere \&quot;attimi della catastrofe adolescenziale\&quot; in uno spazio-tempo negato, nella separazione corporea dal gruppo dei pari e in una relazione scolastica digitale. Studi Sulla Formazione, 23(1), 13-44.

Margiani, V. (2014). Penerapan Strategi Pembelajaran Melalui Bermain Pada Anak Usia Dini Di Taman Penitipan Anak Al-Fitroh Kecamatan Tempel Kabupaten Sleman [Skripsi]. Universitas Negeri Yogyakarta.

Mawarti, S. (2018). Implementasi Media Pembelajaran Visual untuk Perkembangan Kognitif Anak Usia Dini di RA Perwanida Gejugan, Tanjung, Klego, Boyolali Tahun Ajaran 2017/2018 [Skripsi]. IAIN Surakarta.

McQuirter, R. (2020). Lessons on Change: Shifting to Online Learning during COVID-19. Brock Education: A Journal of Educational Research and Practice, 29(2), 47-51.

Mendonça, M. (2020). National Universities in Argentina during the pandemic outbreak. Transformation in Higher Education, 5(0), 9. https://doi.org/10.4102/the.v5i0.91

Mufarikhah Umar, L., \& Nursalim, M. (2020). Studi Kepustakaan Tentang Dampak Wabah Covid-19 Terhadap Kegiatan Belajar Mengajar Pada Siswa Sekolah Dasar (SD). Jurnal BK UNESA, 11(4). https://jurnalmahasiswa.unesa.ac.id/index.php/jurnal-bk-unesa/article/view/34440

Mukholladah, K. Z. (2018). Pengaruh penerapan media video pembelajaran interaktif untuk meningkatkan perkembangan bahasa di TK islam Al-Maarif singosari malang. https://docplayer.info/150865900-Penerapan-media-video-pembelajaran-interaktif-untukmeningkatkan-perkembangan-bahasadi-tk-islam-al-maarif-singosari-malang-skripsi.html

Nadia. (2020). Sistem Pembelajaran Daring Menggunakan Media Online Pada Era Covid-19. OSF Preprints. https://doi.org/10.31219/osf.io/r45ab

Nahdi, K., Ramdhani, S., Yuliatin, R., \& Hadi, Y. (2020). Implementasi Pembelajaran pada Masa Lockdown bagi Lembaga PAUD di Kabupaten Lombok Timur. Jurnal Obsesi: Jurnal Pendidikan Anak Usia Dini, 5, 177. https://doi.org/10.31004/obsesi.v5i1.529

Nurkolis, \& Muhdi. (2020). Keefektivan Kebijakan E-Learning berbasis Sosial Media pada PAUD di Masa Pandemi Covid-19. Jurnal Obsesi : Jurnal Pendidikan Anak Usia Dini, 5(1), 212-228. https://doi.org/10.31004/obsesi.v5i1.535

Oktaria, R., \& Putra, P. (2020). Pendidikan Anak dalam Keluarga sebagai Strategi Pendidikan Anak Usia Dini saat Pandemi Covid-19. Jurnal Ilmiah Pesona PAUD, 7(1), 41-51.

Purwanto, A., Pramono, R., Asbari, M., Santoso, P. B., Wijayanti, L. M., Hyun, C. C., \& Putri, R. S. (2020). Studi Eksploratif Dampak Pandemi COVID-19 Terhadap Proses Pembelajaran Online di Sekolah Dasar. Jurnal of Education, Psychology and Counseling, 2, 1-12.

Rahayu, R. D. (2013). Pengaruh Penggunaan Video Kartun Mencampur Warna Terhadap Kemampuan Kognitif Pada Anak Kelompok B Di Tk Terpadu Al-Hidayah Ii Ds. Bakung Kec. Udanawu Kab. Blitar. PAUD Teratai, 2(2). https://jurnalmahasiswa.unesa.ac.id/index.php/paudteratai/article/view/2432

Rohani. (2019). Media Pembelajaran.

Rukin. (n.d.). Metodologi Penelitian Kualitatif. Yayasan Ahmar Cendekia Indonesia.

Sa'diyah, H. (2019). Peran Guru Mengatasi Peserta Didik Berbicara Kotor Di Kelompok B Raudhatul Athfal Imam Syafi'i Surabaya [Skripsi]. Universitas Islam Negeri Sunan Ampel Surabaya.

Satrianingrum, A. P., \& Prasetyo, I. (2020). Persepsi Guru Dampak Pandemi Covid-19 terhadap Pelaksanaan Pembelajaran Daring di PAUD. Jurnal Obsesi : Jurnal Pendidikan Anak Usia Dini, 5(1), 633-640. https://doi.org/10.31004/obsesi.v5i1.574

SE Mendikbud: Pelaksanaan Kebijakan Pendidikan dalam Masa Darurat Penyebaran Covid-19. (2020, March 24). Kementerian Pendidikan Dan Kebudayaan. 
https://www.kemdikbud.go.id/main/blog/2020/03/se-mendikbud-pelaksanaan-kebijakanpendidikan-dalam-masa-darurat-penyebaran-covid19

Setiawan, A. A., Johan. (2018). Metodologi penelitian kualitatif. CV Jejak (Jejak Publisher).

Suryani, L., \& Seto, S. B. (2020). Penerapan Media Audio Visual untuk Meningkatan Perilaku Cinta Lingkungan pada Golden Age. Jurnal Obsesi : Jurnal Pendidikan Anak Usia Dini, 5(1), 900908. https://doi.org/10.31004/obsesi.v5i1.601

Syukur, A., \& Fallo, Y. T. (2019). Peningkatan Kemampuan Anak dalam Mengenal Konsep Bilangan Melalui Penggunaan Media Pembelajaran Berbasis Alam. Jurnal PG-PAUD Trunojoyo: Jurnal Pendidikan Dan Pembelajaran Anak Usia Dini, 6(1), 1-11. https://doi.org/10.21107/pgpaudtrunojoyo.v6i1.5365

Tartavulea, C. V., Albu, C. N., Albu, N., Dieaconescu, R. I., \& Petre, S. (2020). Online Teaching Practices and the Effectiveness of the Educational Process in the Wake of the COVID-19 Pandemic. The AMFITEATRU ECONOMIC Journal, 22(55), 920-920.

Yusuf, M. (2016). Metode Penelitian Kuantitatif, Kualitatif \& Penelitian Gabungan. Prenada Media.

Zainal, A., Rumansyah, \& Arizona, K. (2020). Pembelajaran Online Berbasis Proyek Salah Satu Solusi Kegiatan Belajar Mengajar di Tengan Pandemi Covid-19. Jurnal Ilmiah Profesi Pendidikan, 5, 64-70.

Zaman, B., \& Eliyawati, C. (2010). Media pembelajaran anak usia dini. 